\title{
The hydrological and the hydrogeological framework of the Lottenbachtal, Bochum, Germany
}

\author{
Mohammad Alhamed
}

Received: 2 March 2014 / Accepted: 16 October 2014/Published online: 9 November 2014

(C) The Author(s) 2014. This article is published with open access at Springerlink.com

\begin{abstract}
This study was performed to investigate the hydrological and the hydrogeological framework of the Lottenbachtal, Germany. Long-term climatic data were statistically analyzed, water and soil samples were collected and analyzed, stream flow discharge was measured and separated, the hydrological balance of this catchment was calculated and a hydrological and hydrogeological conceptual model was constructed. The study area is characterized mainly by the precipitation value ranged between 0.1 and $5 \mathrm{~mm} /$ day. The actual evapotranspiration constitutes $31.90 \%$ of the total precipitation, the direct surface runoff constitutes $61.04 \%$, the soil storage constitutes $3 \%$ and the groundwater recharge of the Lottenbachtal constitutes only $4 \%$ of the total precipitation. The Lottenbachtal has largely affected the diversity of the land use, which includes forests, arable areas, abandoned coal mines and settlement areas. The soil of the forested area is represented by relatively high acidic conditions and relatively high sulfate concentrations, while the soil of the arable areas is represented by near-neutral conditions associated with relatively high concentrations of nutrients and other chemical elements (calcium, magnesium, sodium, potassium,
\end{abstract}

\section{Alhamed}

Department of Geology, Faculty of Science, Damascus

University, Damascus, Syria

\section{Alhamed}

Hydrogeology Department, Faculty of Geoscience, Ruhr

University of Bochum, Bochum, Germany

\section{Alhamed ( $\square)$}

Lehrstuhl für Angewandte Geologie, Fakülitäte für

Geowissenschafter, Universitätstr 150, NA 4/132, 44809

Bochum, Germany

e-mail: mohhedpet@yahoo.com; mohammad.alhamed@rub.de chloride, sulfate, nitrate). The settlement areas are characterized by huge blocks of concrete and backfills, which are rich in calcium and magnesium carbonates. The effects of this diversity in the land use on groundwater and surface water quality resulting by leaching the chemical elements from the soil covers and the other materials. These effects are represented by the following complex water types of $\mathrm{Ca}-\mathrm{Na}-\mathrm{Mg}-\mathrm{Cl}-\mathrm{SO}_{4}-\mathrm{HCO}_{3}, \mathrm{Ca}-\mathrm{Mg}-\mathrm{HCO}_{3}-\mathrm{SO}_{4}, \mathrm{Ca}-\mathrm{Na}-$ $\mathrm{Mg}-\mathrm{Cl}-\mathrm{SO}_{4}, \mathrm{Ca}-\mathrm{Na}-\mathrm{Mg}-\mathrm{Cl}-\mathrm{SO}_{4}$ and $\mathrm{Ca}-\mathrm{HCO}_{3}$, which represent the diversity of the flow paths of the water as well as to mixing processes. The diversity of the land use also affected the physical hydrological-hydrogeological characteristics of the study area by increasing the direct surface runoff and decreasing the groundwater recharge. The impervious surfaces of the settlement areas and the low hydraulic conductivities of the soil covers are responsible for these conditions.

Keywords Hydrological balance - Surface water hydrochemistry - Groundwater hydrochemistry · Hydrological and hydrogeological conceptual model .

Groundwater recharge

\section{Introduction}

Understanding the hydrological cycle and its hydrochemical evolution is a critical issue of the water resources management and the planning in a catchment area. Generally, studying of the hydrological cycle in small watersheds provides high qualitative measurements. These measurements facilitate the investigation of the complexity that results from combinations of the physical, the chemical and the biological processes. In addition, these measurements contribute to understanding the role of the 
environmental variables, such as the change of the land use (Schumann et al. 2010).

Most of the studies performed on small watersheds aimed at estimating the leaching of sediments, nitrogen, and phosphorus in arable areas, while the acidification processes were the main seeking phenomena in the forested areas (Nilssen 1980). Other studies conducted in this field aimed to regionalization the hydrological and hydrogeological parameters obtained from small watersheds to larger watersheds (Lee et al. 2005; Jin et al. 2009).

Underground mining usually affects the hydrological cycle of small catchment areas. These effects, as a result of extractions and stockpile tailing near the mines, are represented by changing geologic, geomorphologic and land use of the exploiting fields (Blodgett et al. 2002). Thus, mining processes changed the flow system of the aquifers in the mining areas. Water quality was also affected by underground mining operations. These effects were represented by high concentrations of undesirable elements (Banks et al. 1997).

Surface mining also affected the hydrological and hydrogeological system of the catchment areas, located within the exploiting zones. These effects resulted from the excavation processes that removed part of the aquifer. Generally, post-mining pit-lakes formed after the mine closure and receive their water from groundwater. Thus, the surface mining consumes the groundwater storage of the aquifers. Moreover, the pit-lakes lose a large portion of their water by evaporation. In addition, materials removed by mining, which are normally barrier to contaminants, increase the possibility of groundwater contamination (Younger 2003). Leaching from tailings and waste rock via soil water and surface runoff cause contamination of groundwater and surface water by toxic constituents, contained in these materials (ELAW 2010).

The conceptual model of small watersheds is an effective tool that facilitates the management and the restoration of streams and watersheds (Cleaves 2003). This model can also help in predicting the impact of some hydrological parameters (Wegehenkel 2002), climate change (Ruelland et al. 2012), or the variations in fracture connectivity (Krzeminska 2012), on the hydrological system.

In the south of Bochum, many coal mines were constructed between the seventeenth and twentieth centuries as a part of Ruhrkarbon mining activities (Hermann and Hermann 2008). Coal deposits were extracted using different methods, including horizontal, inclined and vertical shafts. Deep mining in this area was not conducted until the twentieth century, after the invention of the steam engine (Huske 2006). In addition, dewatering and other facility structures such as adits, drainage adits and shafts were also constructed to facilitate the exploitation process as well as to eliminate dangers associated with mining. Such dangers included the unexpected collapse of the water, drowning whole mines (Hermann and Hermann 2008).

Large amounts of coal were extracted and shipped through the Ruhr, while the resulting mining wastes were dumped near the shafts and entrances (GLA-NRW 1988). During extraction processes, many mines were connected via shafts and other extraction structures, which in turn increased the rate of coal extraction (Huske 2006). Coal mining in this area continued until the beginning of the twentieth century. The mines were either sealed or backfilled using various materials, consisting mainly of mining waste and to a lesser extent ash, garbage, slags, sludge, construction waste, industrial residues and household waste (GLA-NRW 1988).

The main aim of this study is to investigate the hydrological and the hydrogeological framework of the Lottenbachtal catchment area, characterized by a hard rock aquifer that was subjected to mining and urbanization activities as well as to the variety of the land use. Furthermore, the calculation of the components of the hydrological balance in this area is another aim of this research. This research also intended to provide a conceptual model of the study area for sharing with the water sector to restore the channel of the main watercourse of the Lottenbach stream, taking into consideration the ecosystem.

\section{Study area}

The Lottenbachtal catchment area is situated south of Bochum (Fig. 1). The gaged part covers an area of about $5 \mathrm{~km}^{2}$. This area is located within the marine climatic zone of the north-west Germany, characterized by average annual rainfall of $817.6 \mathrm{~mm} / \mathrm{a}$, average air temperature of $2.7{ }^{\circ} \mathrm{C}$ in the winter and $18.5^{\circ} \mathrm{C}$ in the summer, south and south-west winds of mean velocities of $3.5 \mathrm{~ms}^{-1}$, an average value of relative humidity of $75 \%$ and cloudy conditions associated with sunshine duration of 1,229.5 h/a (Grudzielanek et al. 2011). Thus, the climate in the study area is characterized by mild winters and cool summers (LAVUV 2010).

The geology of the study area is represented by the hard rock formations of the Upper Carboniferous as shown in Fig. 2, which consist chiefly of coal seams, mudstone and sandstone deposits (Littke et al. 1986). These deposits were subjected to complex tectonic developments in the Variscan Orogeny, associated with over thrusts, strike slip and normal faults (Littke et al. 1986). These formations form the main aquifer in this area, which is characterized by very low to moderate hydraulic conductivity (GLA-NRWd 1988). 
Fig. 1 Location map of the study area, including the drainage systems, water sampling points and the site of the soil profiles (The drainage systems were modified after Viebahn-Sell 2006)

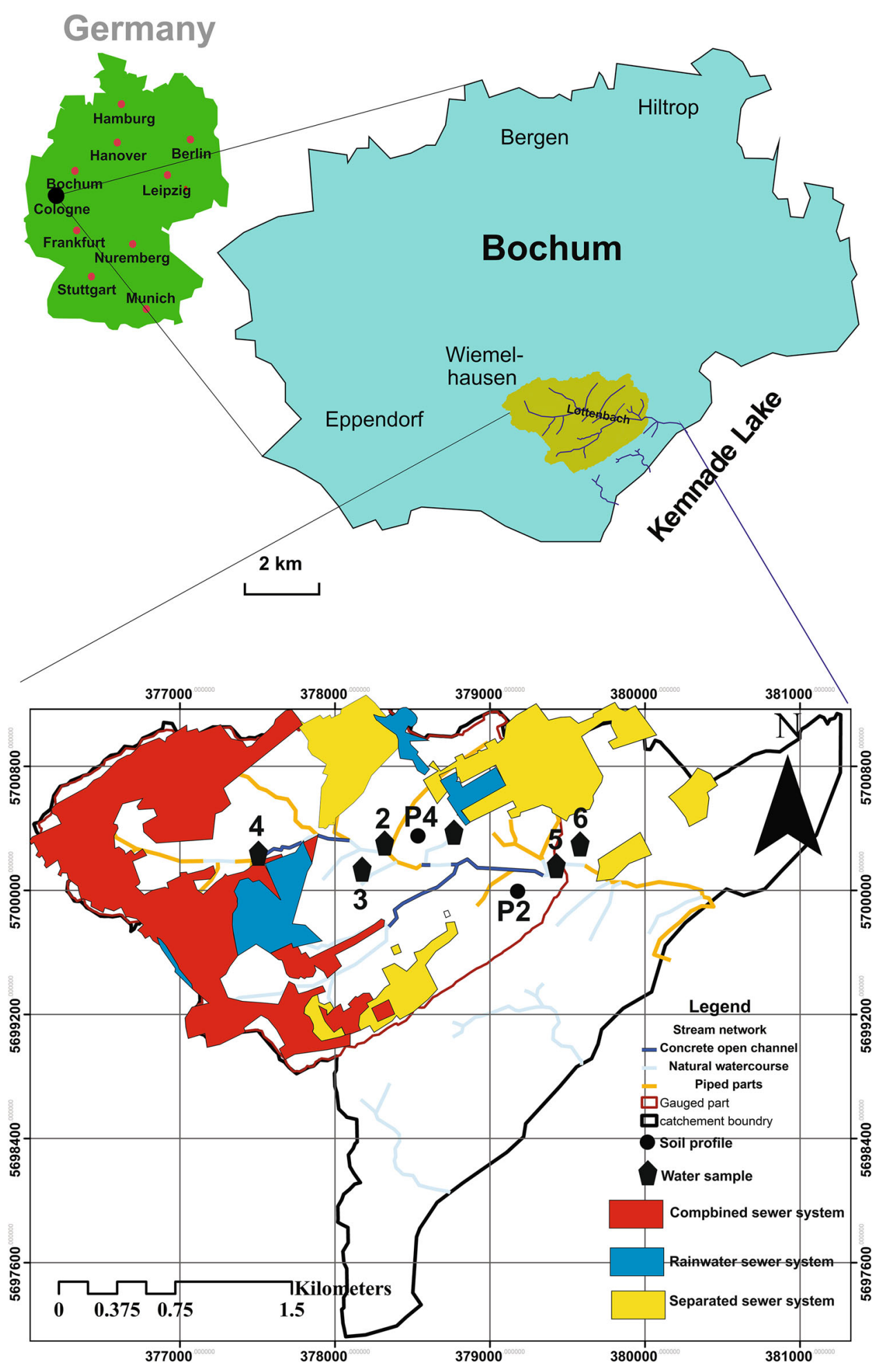

\section{Methodology}

Climatic data for 21 years were obtained from the RudolfGeiger climate station of the Department of Geography in the Faculty of Geoscience at the Ruhr University of Bochum. This data include the daily values of precipitation $P$, average relative humidity $\mathrm{RH}$, minimal air temperature $T_{\min }$, maximal air temperature $T_{\max }$, average air 
Fig. 2 Geological map of the study area (modified after GLANRWa 1988)
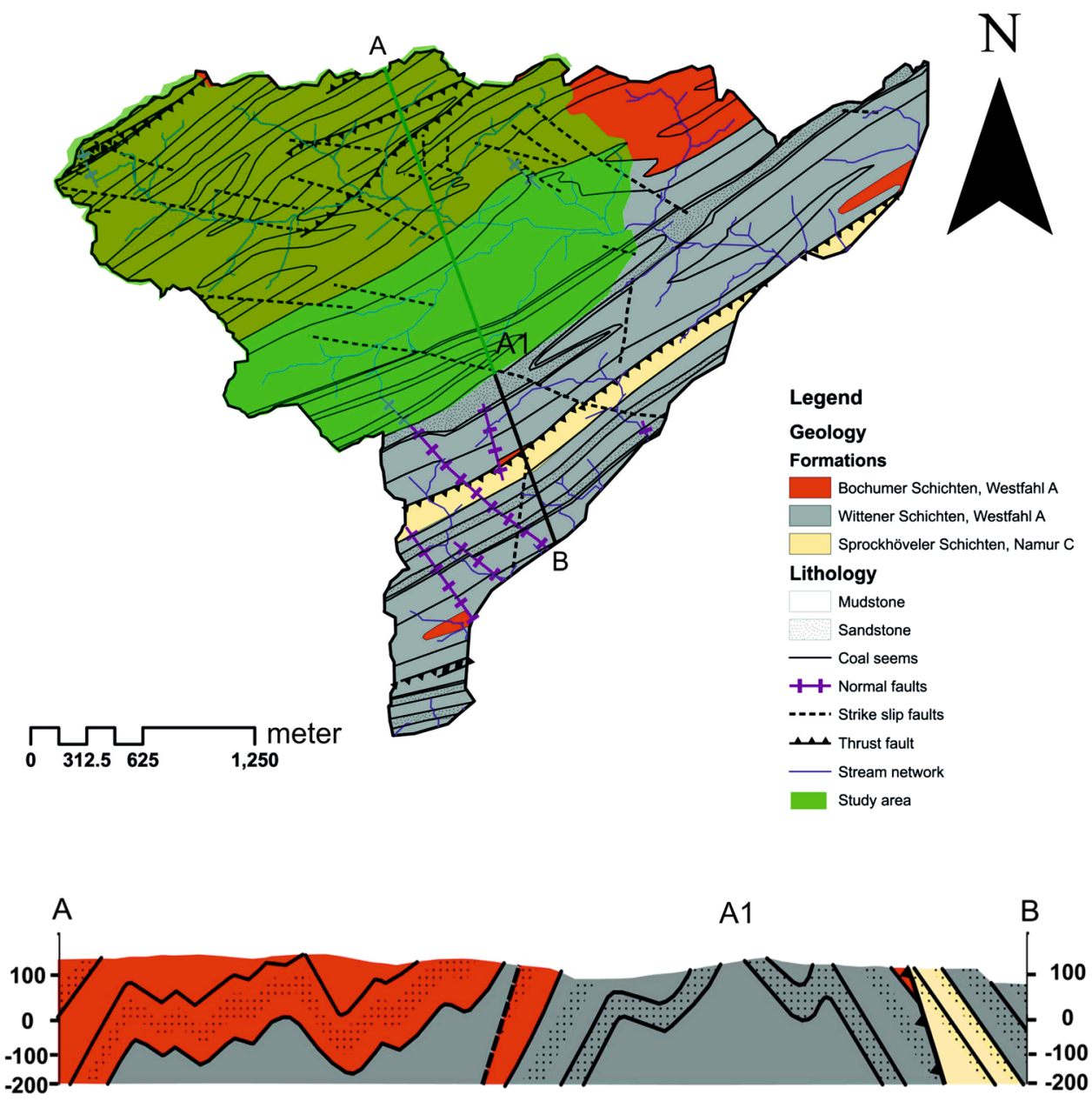

temperature $T_{\text {average }}$ and the average wind velocity $V_{\text {wind }}$ for a period that extended between 1991 and 2012. The frequency analysis of the climatic data was performed by OriginPro V9 (OriginLab Corporation 2012).

$\mathrm{pH}$ according to (DIN 19682-13 2009), electrical conductivity EC according to (DIN ISO 11265 1997), carbonate test according to (DIN 19682-13 2009) and batch test $10 / 1 \mathrm{l} / \mathrm{kg}$ according to (DIN EN 12457-2 2003) were performed on soil samples, collected from the selected soil profiles shown in Fig. 1. The soil profile P2 was chosen in an arable area, while the soil profile $\mathrm{P} 4$ was chosen in a forested area. Major ions including $\mathrm{Ca}^{2+}, \mathrm{Mg}^{2+}, \mathrm{Na}^{+}, \mathrm{K}^{+}$, $\mathrm{Cl}^{-}, \mathrm{SO}_{4}{ }^{2-}$ and $\mathrm{NO}_{3}{ }^{-}$were tested in the extracted samples. A gauge station was installed in the eastern part of the Lottenbach stream to measure the water head of the stream. Van Essen Baro-Diver system was used to achieve this purpose. The recorded water heads were converted to discharge values by instantaneous tracer dilution (Morgenschweis 2010) and volumetric method (FAO 1993).

A total of six well-known water source points were sampled. Water-sample 1 was taken from the drainage system of the Ruhr University of Bochum, water-sample 2 was taken from a mine shaft, water-sample 3 from the shallow groundwater, water-sample 4 was taken from the drainage system of the settlement area in the west, watersample 5 was taken from the Lottenbach stream at the gaging station and water-sample 6 was taken from an open pit lake located in the east of the study area. The location of these samples is shown in Fig. 1. Physico-chemical parameters including $\mathrm{pH}, \mathrm{EC}$, dissolved oxygen DO and redox potential Eh were measured in the field. Concentrations of major ions $\left(\mathrm{Ca}^{2+}, \mathrm{Mg}^{2+}, \mathrm{Na}^{+}, \mathrm{K}^{+}, \mathrm{Cl}^{-}, \mathrm{SO}_{4}{ }^{2-}\right.$, $\mathrm{NO}_{3}{ }^{-}$) were determined in the hydrochemistry laboratory at the Ruhr University of Bochum. $\mathrm{HCO}_{3}{ }^{-}$was calculated by the ion balance equation. The results of the hydrochemical analysis were plotted on piper diagram to determine the hydrochemical facies of the water sources.

The potential evapotranspiration was calculated by the Haude method (Haude 1955). According to the diversity in land use of the study area, the actual evapotranspiration was calculated by integrations of Renger and Wessolek (1990) and Bagrov (1953) and Glugla (1976) methods. The Renger and Wessolek method enables to calculate the actual evapotranspiration of arable, grassland and coniferous-forested areas, 
while Bagrov and Glugla method enables to calculate the actual evapotranspiration of urban area and deciduous forests. The stream hydrograph which was separated into direct surface runoff and base flow by continuous automated timebased separation (Local minimum method) of the stream record. The BFI digital filter version 3 (Hydro-Office; Software for Water Science) was used to achieve this purpose.

The digital filter checks the daily values determining the lowest value of the discharge, which represent a local minimum, in one half the interval minus 1 day $\left[0.5\left(2 n^{*}-1\right)\right.$ days] before and after the day being considered. Then, the local minimums are linked together by straight lines. The area located under the connected lines represents the base flow, while the area located above them represents the direct surface runoff (Sloto and Crouse 1996). The local minimum filter possesses two parameters; $n$ (number of days) and $f$ turning point test factor (Gregor 2010). The values of $n^{*}=5$ and $f^{*}=0.9$ were used for this catchment, where the best match between the measured and calculated base flow was found at these values during low flow conditions.

Groundwater recharge was calculated by a method suggested by (Lillich 1970) for German conditions, where the base flow can consider the groundwater recharge. Soil samples were collected from profiles 2 and 4 to calculate the change in the soil moisture between the initial and the final conditions of the study period. Soil moisture was determined according to (DIN 18121-1 1998). Soil parameter including average of the porosity $\left(n_{\text {soil }}\right)$, which has a value of 0.46 , and average of bulk density, which has a value of $1.4 \mathrm{~g} / \mathrm{cm}^{3}$, was obtained from (Tursun 2012). On the other hand, the mean thickness of the soil cover has a mean value of $1 \mathrm{~m}$ (GLA-NRWc 1988).

Water losses from the settled areas via sewer system were calculated by the water balance equation (Davie 2008), which was modified to fit the hydrological conditions of the study area. This equation is given by

$Q_{\mathrm{urb}}=P-\mathrm{ETa}-\mathrm{GR}-Q_{\mathrm{sur}} \pm \Delta S$

Where $Q_{\text {urb }}$ is surface runoff formed in urban areas, which flows directly into a separate sewer system $(\mathrm{mm})$, $P$ is the precipitation (mm), ETa is the actual evapotranspiration $(\mathrm{mm}), \mathrm{GR}$ is ground water recharge (mm), $Q_{\text {sur }}$ is the surface water runoff, measured at the gaging station of the Lottenbach stream and $\Delta S$ is the change in the soil storage.

The average value of all the parameters at the catchment scale was calculated by the Geographic Information System ArcMap GIS V 9.3 Esri, 2008.

A conceptual model of the study area was established based on the geological, the hydrological and the hydrogeological characteristics of the study area. ArcMap GIS V 9.3 Esri, 2008 and CorelDraw X6 Corel Corporation, 2102 were used to achieve this purpose.

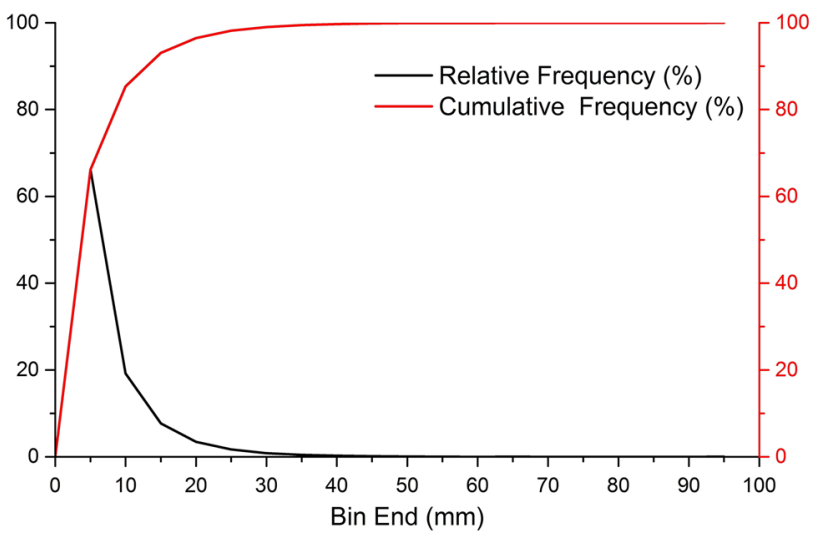

Fig. 3 The relative and the cumulative frequency of the daily precipitation (only rainy days)

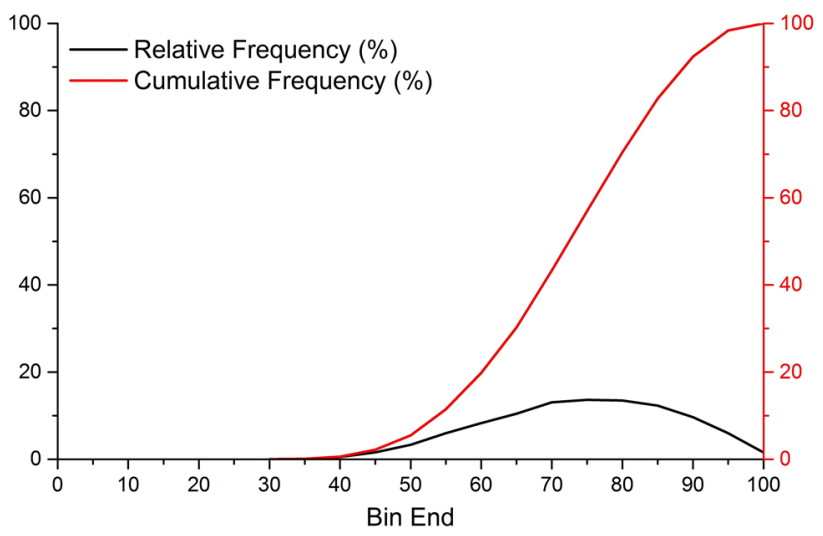

Fig. 4 The relative and the cumulative frequency of the daily relative humidity

\section{Results and discussions}

\section{Hydro-climatic framework}

Figure 3 shows the relative and the cumulative frequency of the daily precipitation (only rainy days). The study area is characterized chiefly by relatively low daily precipitation, when $66 \%$ of the rainy days fall within the range $(0.1-5) \mathrm{mm} /$ day and $19 \%$ of them within (5-10) $\mathrm{mm} /$ day. Smaller relative frequencies of 7.69 and $3.43 \%$ are present for the precipitation domains (10-15) and (15-20) $\mathrm{mm} /$ day, respectively; while a relatively small relative frequency of $1.71 \%$ exists for the domain (20-25) $\mathrm{mm} / \mathrm{day}$. Other precipitation ranges, up to $45 \mathrm{~mm} /$ day, have a relative frequency less than $0.1 \%$.

Relative humidity shows more homogeneous conditions as shown in Fig. 4. The relative frequencies of the $\mathrm{RH}$ domains lie in two main extents of $(5 \%<\mathrm{RF}<10 \%)$ and $(10 \%<\mathrm{RF}<15 \%)$. RH domains of [(45-50), (50-55), (80-85), (85-90)] belong to the first extent, while the domains of $[(55-60),(60-56),(65-70),(70-75)$, 


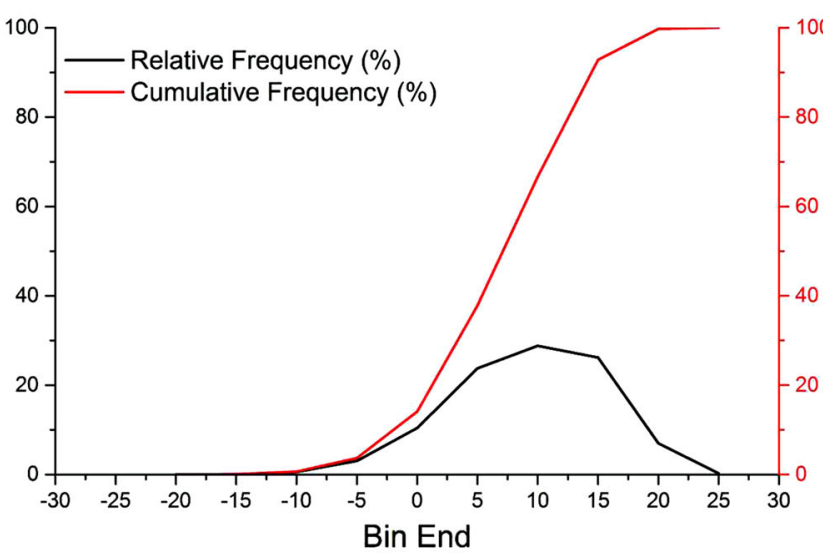

Tmin

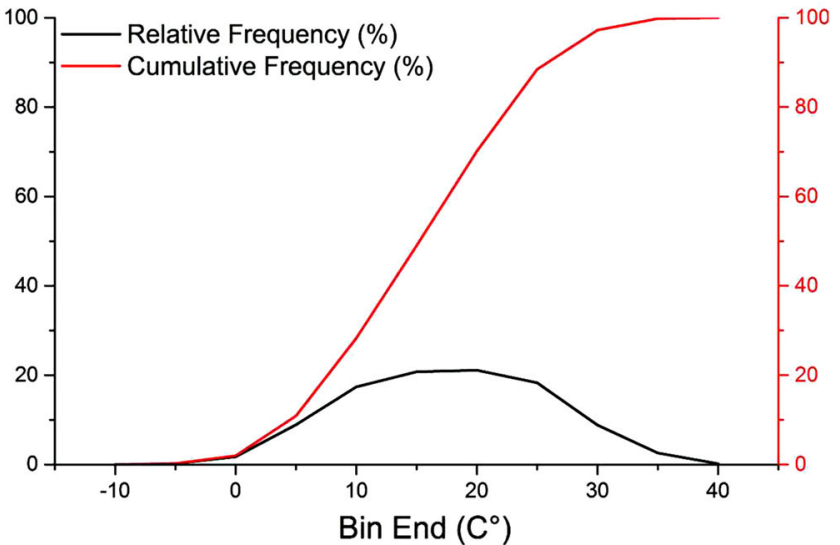

Tmax

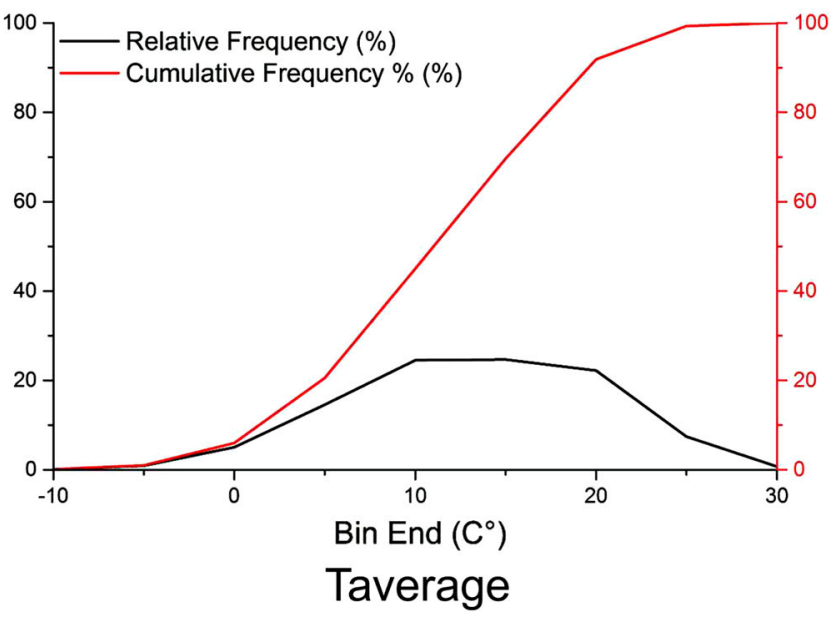

Fig. 5 The relative and the cumulative frequency of the daily $T_{\min }, T_{\max }$ and $T_{\text {average }}$

(75-80)] belong to the second one. However, domains of $[(35-40), \quad(40-45), \quad(90-95)] \%$ fall in the range $(1 \%<\mathrm{RF}<5 \%)$. Saturation conditions and high deficit conditions of the vapor are very rare and have a very low relative frequency.

The study area characterized by mild winter that is represented by the predominance of the $T_{\min }$ ranges of $[(0-5),(5-10),(0-15)]{ }^{\circ} \mathrm{C}$, located within the RF extent of $(20 \%<\mathrm{RF}<30 \%)$ and the ranges of $[(-10$ to -5$)$, ( -5 to -0$)$ and $(15-20)]{ }^{\circ} \mathrm{C}$ located within the RF extent of $(3 \%<\mathrm{RF}<10 \%)$. Very cold periods are extremely rare in this area. This situation represented by the very low relative frequency (less than $1 \%$ ) is found in very low $T_{\min }$ ranges of ( -20 to -15$)$ and $(-15$ to -10$)$. High $T_{\min }$ values are also rare in this area, represented by $\mathrm{RF}$ values less than $1 \%$. For daily maximal temperature, RF values less than $1 \%$ were found in the $T_{\max }$ domains [(-15 to -10$),(-10$ to -5$),(35-40)]{ }^{\circ} \mathrm{C}$. RF values of $(1<\mathrm{RF}<15 \%)$ were found for the relatively low $T_{\max }$ of the winter and the relatively high $T_{\max }$ in the summer, represented by $T_{\max }$ domains [( -5 to 0$),(0-5),(25-30)$, (30-35)] ${ }^{\circ} \mathrm{C}$. The moderate $T_{\max }$, represented by domains [(5-10), (10-15), (15-20), (20-25), falls within the range $(15<\mathrm{RF}<20 \%)$. The relative and the cumulative frequencies of the $T_{\min }, T_{\max }$ and $T_{\text {average }}$ are shown in Fig. 5.

\section{Soil chemistry}

The results of the $\mathrm{pH}, \mathrm{EC}$ and batch tests, performed on soil profiles P2 and P4 are shown in Figs. 6 and 7, respectively. The soil profile $\mathrm{P} 2$, sampled from an arable area, is characterized by near-neutral to neutral conditions. This is because that the $\mathrm{pH}$ values range between 5.53 at the level (10-20) and 6.57 at the level (90-100) as shown in Fig. 6. A relatively low $\mathrm{pH}$ value was noted in the topsoil horizon up to $40 \mathrm{~cm}$ depth. After that, the $\mathrm{pH}$ values increase until reaching the maximum value in the level (90-100). An 


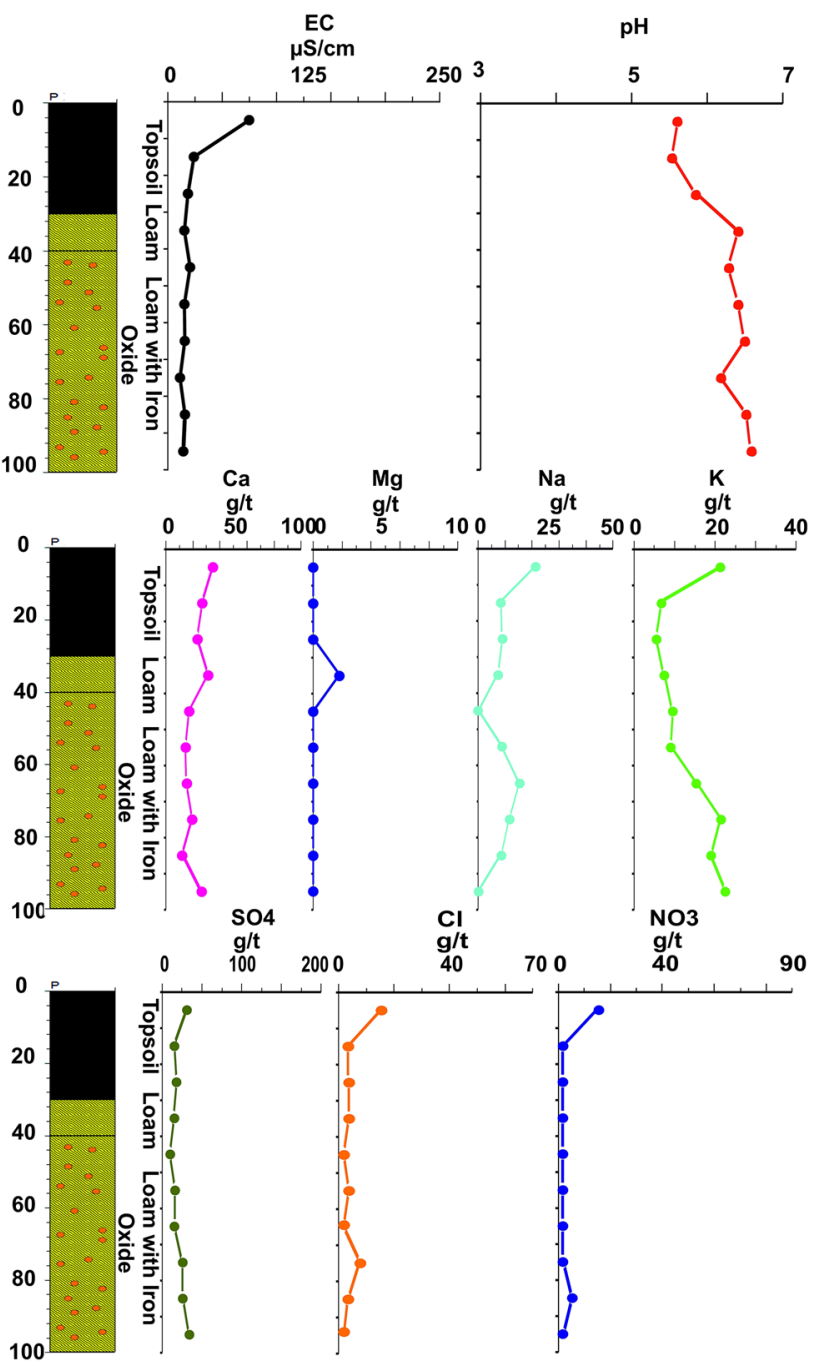

Fig. 6 Results of the $\mathrm{pH}, \mathrm{EC}$ and batch tests, performed on soil profiles $\mathrm{P} 2$ (arable area)

oscillation of the $\mathrm{pH}$ value can be seen explicitly along this profile. The average value of the $\mathrm{pH}$ in this profile is 6.17 . EC shows more stability in comparison with $\mathrm{pH}$. Its value ranges between 15.24 and $74.80 \mu \mathrm{s} / \mathrm{cm}$. The minimum value was measured at the level (30-40), whereas the maximum value was measured at the level $(0-20)$. These conditions are associated with a poor carbonate content of $(0.5<\mathrm{CO} 3<2 \%)$ along this profile. In addition, samples collected from this profile are characterized by low concentration of major ions. The $\mathrm{Ca}^{2+}$ concentrations range between $12.01 \mathrm{~g} / \mathrm{t}$, measured at the level (80-90) and $34.07 \mathrm{~g} / \mathrm{t}$, measured at the top level $(0-10)$. The $\mathrm{Ca}^{2+}$ has an average value of $21.58 \mathrm{~g} / \mathrm{t}$. The $\mathrm{Mg}^{2+}$ concentrations show undetectable values along this profile. An exception was found at the level (30-40) with a very low content of $1.84 \mathrm{~g} / \mathrm{t}$. In these circumstances, the measuring errors should be considered for this element. The $\mathrm{Na}^{+}$and the $\mathrm{K}^{+}$ concentrations have close ranges. The $\mathrm{Na}^{+}$values fall

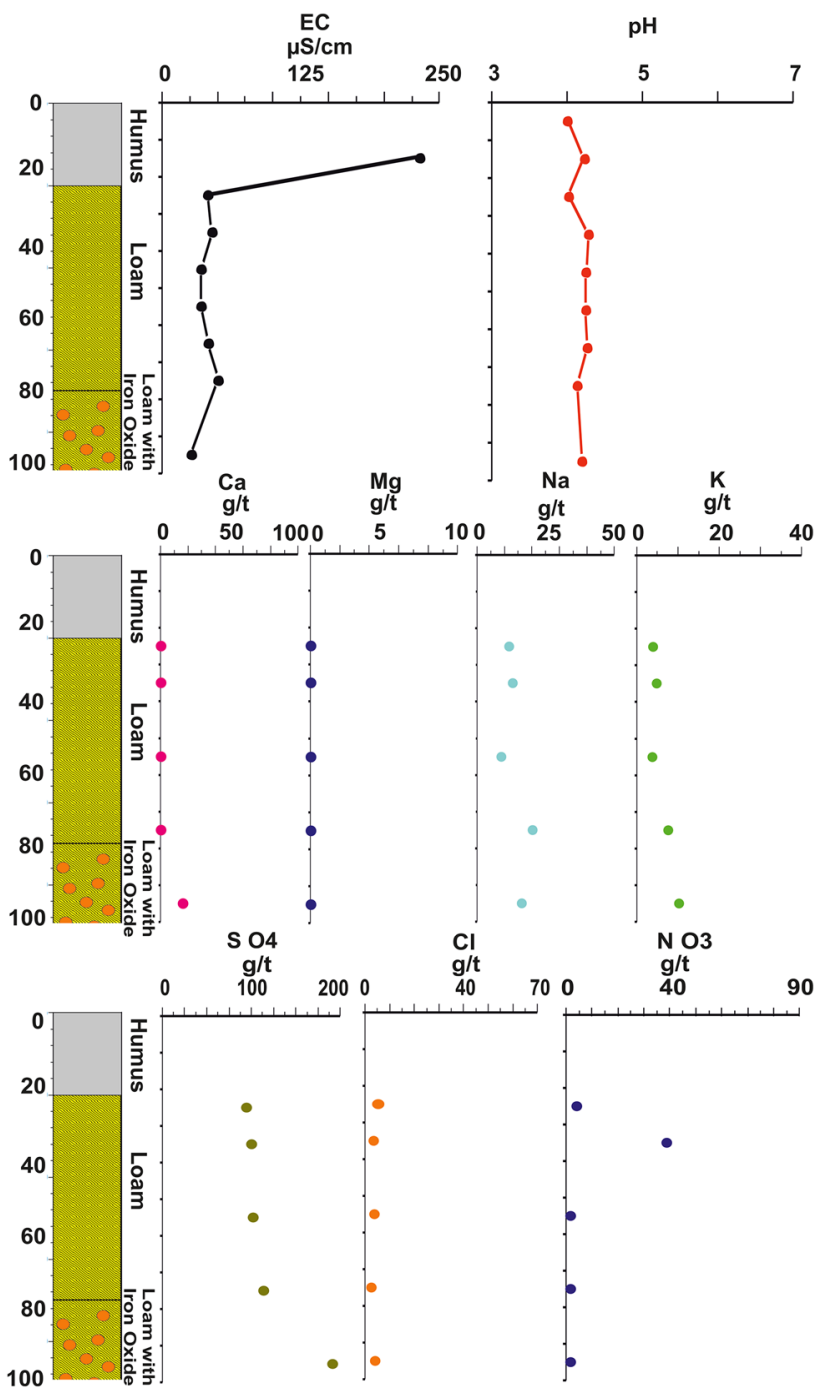

Fig. 7 Results of pH test, EC test and batch test of the soil profile P4 (forested area)

within the range (undetectable-21.21) $\mathrm{g} / \mathrm{t}$, while $\mathrm{K}^{+}$falls within the range $(5.38-22.50) \mathrm{g} / \mathrm{t}$. The minimum of $\mathrm{Na}^{+}$ measured at the levels (40-50 and 90-100), while the maximum measured at the top level $(0-10)$. Conversely, the minimum of $\mathrm{K}^{+}$measured at the level (20-30) and the maximum measured at the level $(90-100) \mathrm{g} / \mathrm{t}$. The average values of $\mathrm{Na}^{+}$and $\mathrm{K}^{+}$in this profile are 10.04 and $12.74 \mathrm{~g} /$ $\mathrm{t}$, respectively.

For anions, $\mathrm{SO}_{4}{ }^{2-}$ ranges between $9.48 \mathrm{~g} / \mathrm{t}$, measured at the level (40-50) and $33.75 \mathrm{~g} / \mathrm{t}$, measured at the level (90-100). The average value of the $\mathrm{SO}_{4}{ }^{2-}$ in this profile is $18.94 \mathrm{~g} / \mathrm{t} . \mathrm{Cl}^{-}$shows relatively low concentration in comparison with other elements. The maximum value of $15.42 \mathrm{~g} / \mathrm{t}$ was measured at the top level $(0-10)$, while concentrations less than $1.77 \mathrm{~g} / \mathrm{t}$ were measured at the levels (40-50) and (60-70). The average value of $\mathrm{Cl}^{-}$in this profile is $4.93 \mathrm{~g} / \mathrm{t} . \mathrm{NO}_{3}{ }^{-}$shows values less than 1.77 
along the soil profile, except for levels (0-10) and (80-90) where values of $15.42 \mathrm{~g} / \mathrm{t}$ and $5.15 \mathrm{~g} / \mathrm{t}$ were measured, respectively.

On the other hand, the soil profile P4 was sampled from a forested area. This profile shows more acidic condition than the P2 as shown in Fig. 7. The $\mathrm{pH}$ values of $\mathrm{P} 4$ range between 4 , measured at the top of the humus level and 4.28, measured at the level (30-40). The average value of $\mathrm{pH}$ in this profile is 4.16 . The $\mathrm{pH}$ values along this soil profile are more stable than P2. The EC shows a very high value of $232 \mu \mathrm{s} / \mathrm{cm}$ in humus, while the unconsolidated materials located at the level (90-100) have the minimum value of $26.2 \mu \mathrm{s} / \mathrm{cm}$. The average of the EC in this profile is $63.34 \mu \mathrm{s} / \mathrm{cm}$. All sampled points in this profile show undetectable values for $\mathrm{Ca}^{2+}$ (Fig. 7). An exception was found in the unconsolidated materials situated at the level (90-100), where the $\mathrm{Ca}^{2+}$ has a value of $16.26 \mathrm{~g} / \mathrm{t}$. The $\mathrm{Mg}^{2+}$ has undetectable values for all sampled levels, whereas $\mathrm{Na}^{2+}$ has an extent that asymptotically matched its extent in profile P2. Its value ranges between $8.75 \mathrm{~g} / \mathrm{t}$ at the level (50-60) and $20.16 \mathrm{~g} / \mathrm{t}$, at the level (70-80). The average value of the $\mathrm{Na}^{+}$is $13.08 \mathrm{~g} / \mathrm{t}$. The $\mathrm{K}^{+}$concentrations have a less extended range in comparison with $\mathrm{P} 2$. Its value ranges between $3.75 \mathrm{~g} / \mathrm{t}$, measured at the level (50-60) and $10.17 \mathrm{~g} / \mathrm{t}$, measured at the level (90-100). The average value of $\mathrm{K}^{+}$in this profile is $5.63 \mathrm{~g} / \mathrm{t}$.

For anions, $\mathrm{SO}_{4}{ }^{2-}$ concentrations extend between 94.19 and $191.17 \mathrm{~g} / \mathrm{t}$ specifying a more extensive range than the profile P2. The maximum was measured at the level (90-100), while the minimum was measured at the level (20-30). The average value of the $\mathrm{SO}_{4}{ }^{2-}$ in this profile is $115.68 \mathrm{~g} / \mathrm{t}$. The $\mathrm{Cl}^{-}$concentrations in this profile show similar conditions compared with $\mathrm{P} 2$ and are also characterized by low concentrations. The maximum value of $5.16 \mathrm{~g} / \mathrm{t}$ was measured at the top level $(0-10)$, while the minimum value of $2.52 \mathrm{~g} / \mathrm{t}$ was measured at the levels (70-80). The average value in this profile is $3.59 \mathrm{~g} / \mathrm{t} . \mathrm{NO}_{3}{ }^{-}$ shows a relatively high concentration of $38.76 \mathrm{~g} / \mathrm{t}$ at the level (30-40), while values less than $1.77 \mathrm{~g} / \mathrm{t}$ were measured at most levels along this profile as shown in Fig. 7.

The differences in the element concentrations represent the impact of the variety of the land use on the soil chemistry. The high concentrations of the $\mathrm{SO}_{4}{ }^{2-}$, associated with high concentrations of $\mathrm{H}^{+}$, in the forested area could be resulted from the high organic sulfur content (Mayer et al. 1995), compared to the arable areas. On the other hand, the high concentrations of the other elements in soil samples collected from the arable field may be related to the soil treatment and the agricultural activities. The agricultural activities are responsible for higher concentrations of these elements in the topsoil horizon in comparison with the underlying zones.
Table 1 The results of hydrochemical analysis of the water samples collected from the study area

\begin{tabular}{llllllll}
\hline Parameter & unit & \multicolumn{2}{l}{ Sample no } \\
\cline { 3 - 8 } & & 1 & 2 & 3 & 4 & 5 & 6 \\
\hline $\mathrm{EC}$ & $\mu \mathrm{s} / \mathrm{cm}$ & 1,364 & 923 & 459 & 381 & 511 & 482 \\
$\mathrm{DO}$ & $\mathrm{mg} / 1$ & 8.25 & 6.72 & 7.15 & 9.87 & 9.74 & 6.76 \\
$\mathrm{pH}$ & - & 7.81 & 7.22 & 6.45 & 7.78 & 7.30 & 7.43 \\
$\mathrm{EH}$ & $\mathrm{mv}$ & 395 & 168 & 455 & 401 & 392 & 317 \\
$\mathrm{Ca}$ & $\mathrm{mg} / \mathrm{l}$ & 113.00 & 124.00 & 33.50 & 37.90 & 66.90 & 124.00 \\
$\mathrm{Mg}$ & $\mathrm{mg} / 1$ & 38.00 & 26.00 & 12.80 & 9.40 & 14.10 & 14.00 \\
$\mathrm{Na}$ & $\mathrm{mg} / 1$ & 105.00 & 37.50 & 29.30 & 14.90 & 16.70 & 18.70 \\
$\mathrm{~K}$ & $\mathrm{mg} / 1$ & 18.80 & 9.70 & 4.60 & 9.30 & 2.80 & 3.40 \\
$\mathrm{SO}$ & $\mathrm{mg} / 1$ & 242.00 & 135.00 & 67.30 & 47.00 & 63.80 & 63.00 \\
$\mathrm{Cl}$ & $\mathrm{mg} / 1$ & 193.00 & 52.20 & 57.00 & 32.40 & 33.70 & 31.30 \\
$\mathrm{NO}_{3}$ & $\mathrm{mg} / 1$ & 5.50 & 2.10 & 37.90 & 12.80 & 11.70 & 5.60 \\
\hline
\end{tabular}

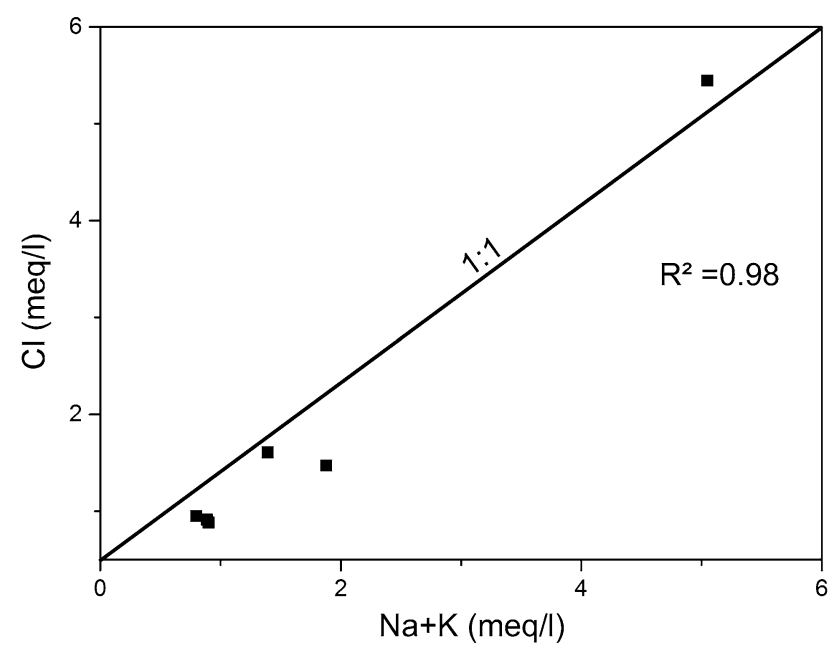

Fig. 8 The correlation between the $\mathrm{Na}^{+}+\mathrm{K}^{+}$and $\mathrm{Cl}^{-}$of the water samples collected from the Lottenbachtal

\section{Hydrochemical characteristics}

The results of the hydrochemical parameters, measured in the water samples collected from the Lottenbachtal catchment area, are presented in Table 1. The water samples are characterized by neutral conditions, when $\mathrm{pH}$ varies from 6.45 in the shallow groundwater and 7.81 in the drainage system of the Ruhr University of Bochum. EC values ranged between $381 \mu \mathrm{s} / \mathrm{cm}$ in the drainage system of the settlement area in the west and $1364 \mu \mathrm{s} / \mathrm{cm}$ in the drainage system of the Ruhr University of Bochum.

The concentrations of $\mathrm{Na}^{+}$and $\mathrm{K}^{+}$vary from 14.9 to 105 and $2.8-18.8 \mathrm{mg} / \mathrm{l}$, respectively. The $\mathrm{Ca}^{2+}$ and $\mathrm{Mg}^{2+}$ concentrations extend from 33.5 to 124 and 9.4 to $38 \mathrm{mg} / \mathrm{l}$, respectively. For anions, $\mathrm{SO}_{4}{ }^{2-}, \mathrm{Cl}^{-}$and $\mathrm{NO}_{3}{ }^{-}$concentrations range between 47 and 242, 31 and 193 and 2.1 and $37.9 \mathrm{mg} / \mathrm{l}$, respectively. 
Fig. 9 The Piper diagram of the water sample collected from the Lottenbachtal catchment area
Piper Diagram

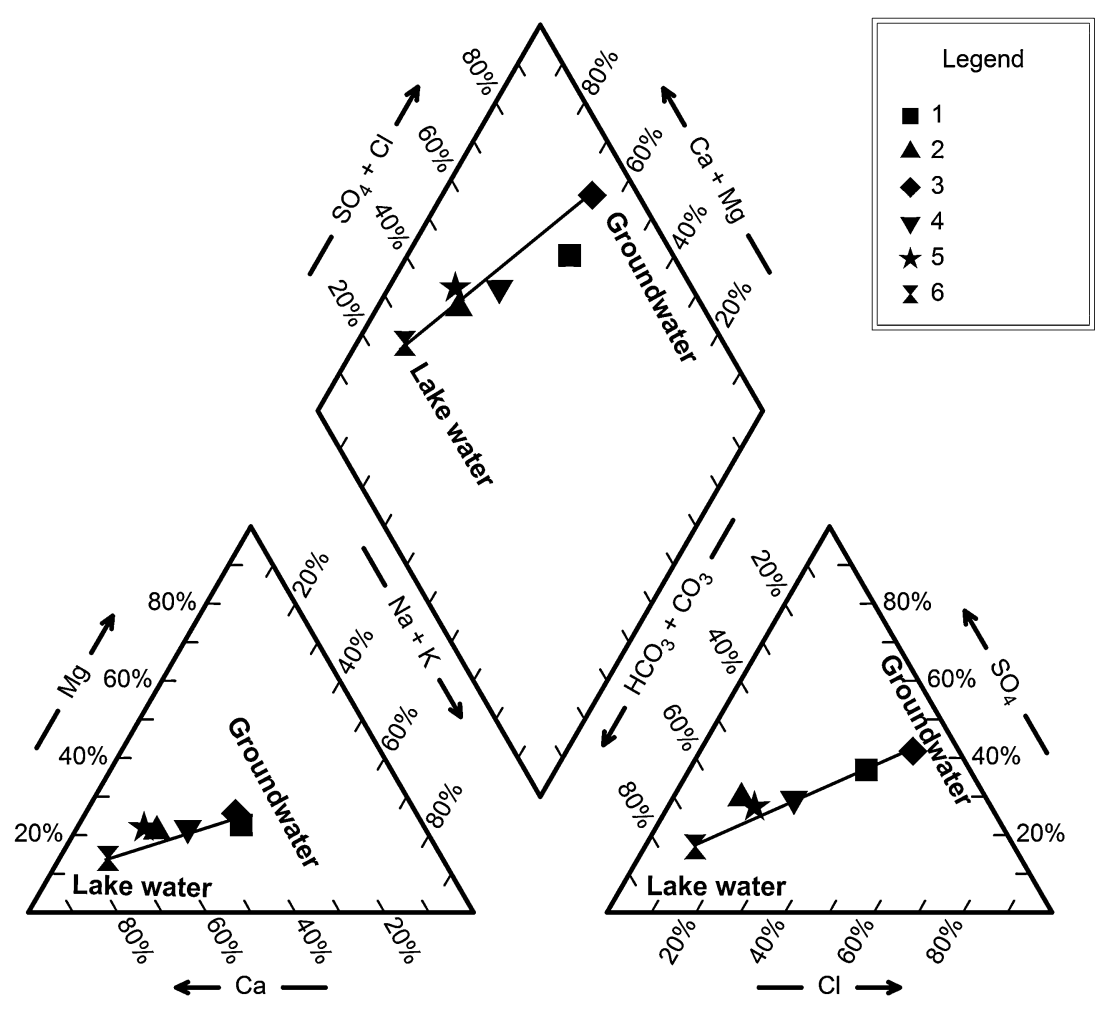

The relatively high concentrations of $\mathrm{Ca}^{2+}, \mathrm{Mg}^{2+}$ and $\mathrm{HCO}_{3}{ }^{-}$in the surface water and groundwater in this area are derived from calcium-rich materials, which include backfill, construction materials, mine waste and the geological formations (Alhamed 2014). The soil of the arable fields also contains $\mathrm{Ca}^{2+}$ and $\mathrm{HCO}_{3}{ }^{-}$(Fig. 6). So that, flow of soil water through the soil section increases the calcium and carbonate content of the percolated water. Thus, the agricultural activities also contribute to the evolution of the chemical composition of the surface water and groundwater. These conditions relate to the leaching of nutrients, especially from the topsoil (Fig. 6), into stream water and groundwater.

The $\mathrm{Na}^{+}, \mathrm{K}^{+}$and $\mathrm{Cl}^{-}$concentrations in the water samples are mostly related to dissolution of road salt used largely in the winter. This related to the existing sampling points next to road or settlement areas. The high correlation between $\mathrm{Na}^{+}+\mathrm{K}^{+}$and $\mathrm{Cl}^{-}$in Fig. 8 enhances this hypothesis.

However, $\mathrm{Na}^{+}$and $\mathrm{K}^{+}$can also result from the weathering of silicate minerals (Alhamed 2014). This is represented by the slight deviation of the relation $\mathrm{Na}^{+}+\mathrm{K}^{+}: \mathrm{Cl}^{-}$ from the 1:1 line toward the $\mathrm{Na}^{+}+\mathrm{K}^{+}$in Fig. 8 .

The top soil horizon of the arable fields also contains $\mathrm{Na}^{+}, \mathrm{K}^{+}$and $\mathrm{Cl}^{-}$(Fig. 6). The most likely source of these elements in this area is the fertilization. These elements can be dissolved in the soil water, which flows into surface water and groundwater, to increase the concentration of these elements in both groundwater and surface water. The $\mathrm{NO}_{3}{ }^{-}$contents of the surface water and the groundwater are resulted mainly by the leaching from the topsoil horizon of the study area, which has a relatively high concentration of this element as shown in Fig. 6 and Fig. 7. The main source of the $\mathrm{NO}_{3}{ }^{-}$in the arable soil is the fertilization. However, wet and dry deposition (Langguth and Voigt 2004) could also contribute to the $\mathrm{NO}_{3}{ }^{-}$and other elements of the groundwater and the surface water of this area (Alhamed and Wohnlich 2014b). The abandoned coal mines of this area also affected the hydrochemical characteristics of the surface water and the groundwater. These effects are represented by the main content of the $\mathrm{SO}_{4}{ }^{2-}$ and additional concentrations of the $\mathrm{Ca}^{2+}$, the $\mathrm{Mg}^{2+}$ and the $\mathrm{HCO}_{3}{ }^{-}$in the surface water and groundwater as discussed in Alhamed (2014), Alhamed and Wohnlich (2014a).

The results of the hydrochemical analysis were plotted on the Piper diagram (Fig. 9) to determine the hydrochemical facies of the water resources in the Lottenbachtal catchment area.

Five main water types were found in the study area, which are $\mathrm{Ca}-\mathrm{Na}-\mathrm{Mg}-\mathrm{Cl}-\mathrm{SO}_{4}-\mathrm{HCO}_{3}$ in the drainage system of the Ruhr University of Bochum, $\mathrm{Ca}-\mathrm{Mg}-\mathrm{HCO}_{3}-\mathrm{SO}_{4}$ in the mine shaft and the stream water, $\mathrm{Ca}-\mathrm{Na}-\mathrm{Mg}-\mathrm{Cl}-\mathrm{SO}_{4}$ in the urban water, $\mathrm{Ca}-\mathrm{Na}-\mathrm{Mg}-\mathrm{Cl}-\mathrm{SO}_{4}$ in the shallow 

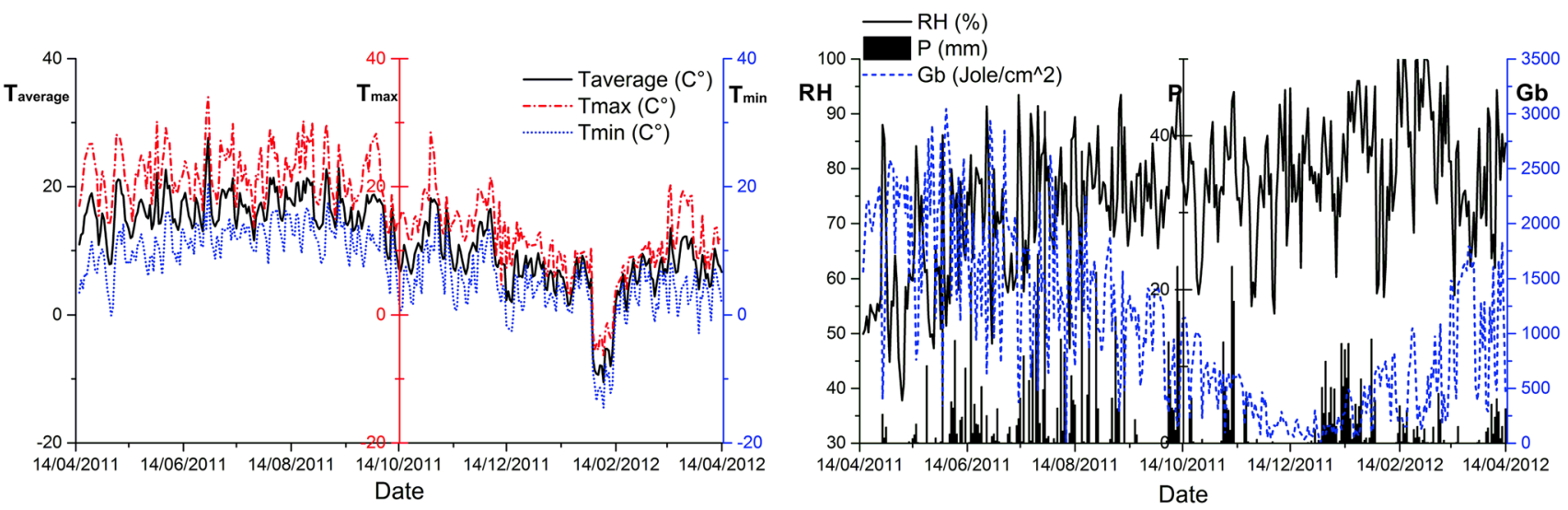

Fig. 10 The climatic parameters used in the water balance calculations

Fig. 11 The result of stream flow discharge measurements of the Lottenbachtal

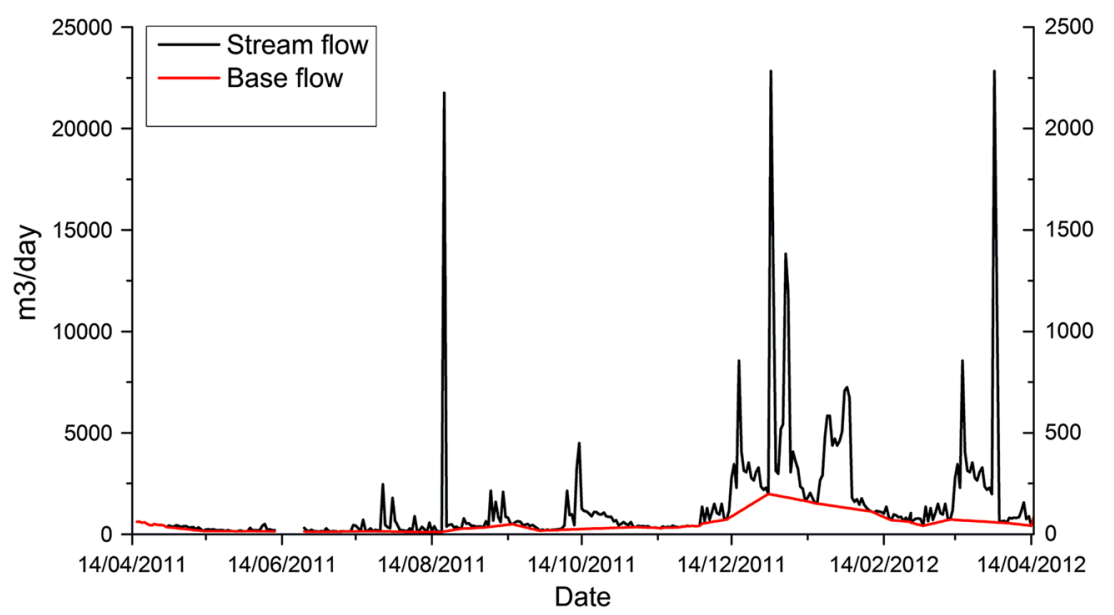

groundwater and $\mathrm{Ca}-\mathrm{HCO}_{3}$ in the open pit lake. These facies are an indicator of the complexity controlling the evolution of the surface water and groundwater hydrochemistry, where the mixing processes and the multi-flow paths are the main factors responsible for the formation of the above-mentioned water types. This conclusion was introduced by the result of batch test performed on soil and artificial materials (Alhamed 2014), where wide range of concentrations was found in these materials. Significant variability of the soil chemistry could also be seen in Figs. 6 and 7, where important differences can be clearly seen between the soil samples of the arable and the forested area. In addition, differences in the concentrations can be seen for each element along each profile.

The linear trend of the hydrochemical properties, shown in Fig. 9, from the lake water toward the groundwater is another indicator of the water mixing and the variety of the flow paths. These conditions also refer to contribute different types of water, results from different sources, to the groundwater and the surface water.
The hydrological and the hydrogeological conceptual model

Figure 10 shows the climatic parameter, including the daily precipitations, the daily average of the air temperatures, the minimal and the maximal daily air temperatures, the daily average of the relative humidity and the daily sum of the global radiations Gb. Figure 11 shows the stream flow discharge, separated into its main components.

According to the climatic data (Fig. 10), the measured stream flow, the soil moisture and the other hydrological parameters, the hydrological budget of the gaged part of the Lottentalbach catchment area can be described as follows; the annual precipitation during the study period is $944.5 \mathrm{~mm}$, average of relative humidity is $61.74 \%$, average of air temperature at $14: 00 \mathrm{~h}$ is $14.09{ }^{\circ} \mathrm{C}$, the average of $T_{\max }$ is $16.36{ }^{\circ} \mathrm{C}$, the average of the $T_{\min }$ is $7.2^{\circ} \mathrm{C}$ and the average of mean temperature is $11.55^{\circ} \mathrm{C}$. The minimal air temperature value of $-14.5^{\circ} \mathrm{C}$ was measured in the winter, and the maximal value of $34{ }^{\circ} \mathrm{C}$ was measured in 
Fig. 12 The hydrological and the hydrogeological conceptual model of the Lottenbachtal (the section A1:A of the geological profile shown in Fig. 1)

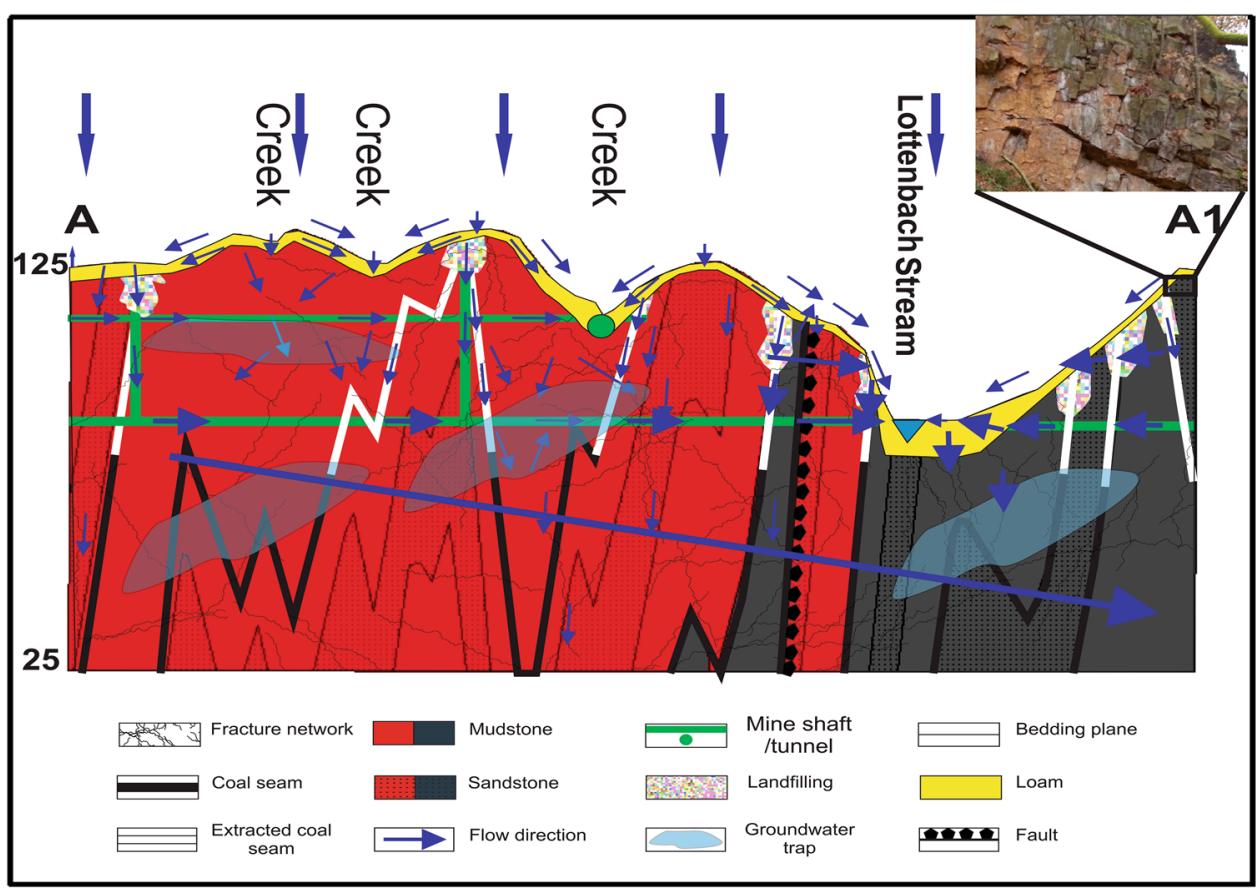

the summer. The actual evapotranspiration value during the study period, resulted by integration of Renger and Wessolek and Bagrov and Glugla methods, is $301.25 \mathrm{~mm}$.

The total stream flow during the study period is $497,863 \mathrm{~m}^{3}(99.57 \mathrm{~mm})$, while the total value of the base flow is $192,049 \mathrm{~m}^{3}(38.41 \mathrm{~mm})$. On the other hand, the total value of the direct surface runoff during the study period is $305,815 \mathrm{~m}^{3}(61.16 \mathrm{~mm})$. The mean change in the soil moisture is $24 \mathrm{~mm}$, which represents $122,218 \mathrm{~m}^{3}$.

Thus, the total stream flow constitutes only $10.5 \%$ of the total precipitation, where the base flow constitutes $4 \%$ and the direct surface runoff, which flow into the stream, constitutes $6.5 \%$. The change in the soil moisture constitutes only $3 \%$, whereas the actual evaporation constitutes $32 \%$. The direct surface runoff (water losses), generated over the urban area, should be $54.56 \%$ of the total precipitation. Thus, the total direct surface runoff in this area constitutes $61 \%$ of the total precipitation.

The catchment area of Lottenbachtal is characterized by mountainous structure, represented by shallow hills separated by steep sloped V-notched valleys (GLA-NRW 1988). The Lottenbach stream, which is the main watercourse in the study area, represented by small tributaries. These tributaries are characterized by notched bottom as well as to low gradient (Viebahn-Sell 2001). Therefore, this stream was classified as a small floodplain in the basement (Viebahn-Sell 2006).

The land use of gaged part of the Lottenbachtal catchment area consists mainly of urban districts with $54 \%$ of the total area. This includes the residential area, transport and other facilities. Conversely, agricultural fields constitute $13 \%$ of the total area, and consist mainly of wheat fields. Grassland forms $11 \%$ of the area, which is used as open pastures. Deciduous forests comprise $10 \%$, and consist mainly of beech. Mixing land of weeds and shrubbery also constitute $10 \%$. Coniferous forests, consisting mainly of spruce, occupy $1 \%$.

According to the classification of the United States department of agriculture (USAD 2007), the soil cover of the Lottenbachtal catchment area consists mainly of D hydrological soil group (HSG), which has a mean hydraulic conductivity of $4.62 \times 10^{-6} \mathrm{~m} / \mathrm{s}$ (GLA-NRWb 1988). This soil group is normally characterized by low to very low hydraulic conductivity, associated with high potential runoff. The hydrologic soil group $\mathrm{C}$ occupies a small portion of the study area (GLA-NRWb 1988). This group extends as narrow belt with a southwest-northeast direction and is characterized by the low hydraulic conductivity of about $8.1 \times 10^{-5} \mathrm{~m} / \mathrm{s}$ (GLA-NRWb 1988). Thus, the hydrological characteristics of the soil cover in the study area increase the potential runoff and reduce the groundwater recharge.

The western part of the study area and the most of the settlement area are drained by a separate sewer system (Fig. 1). Thus, the direct surface runoff of this area does not reach the Lottenbach stream.

A conceptual model of the study area is shown in Fig. 12. The Upper Carboniferous mudstone and sandstone deposits are the main aquifers in this area. These formations are overlaid by loess deposits, which are 
characterized by low hydraulic conductivity and constitute an aquitard.

Figure 12 shows that the groundwater flow takes place chiefly through faults and mine shafts. These features form high flow conduits of the groundwater. Fracture networks, joints and bedding planes form other flow paths. Fractures are scattered within the impermeable rock matrix, so that groundwater could also flow through the primary pore space and fracture networks. In addition, the intersection between the faults, joints and bedding planes systems could form local traps of the groundwater. Joints and bedding planes enhance the vertical and semi-vertical groundwater flow. However, the complex interconnection between fractures, fault, shafts and bedding planes increases the heterogeneity and the complexity of the groundwater flow system in this area. The intersection points between these features and the earth's surface could contribute in the formation of water springs on the slopes or at the bottom of the valleys (Fig. 12). Figure 12 also shows that the groundwater, including the mine water, occurs chiefly by infiltration of the precipitation through the mine facilities, the faults, the joints, the bedding planes and the fracture networks. This hypothesis enhanced by the hydrogeological characteristics of the shallow groundwater, represented by $\mathrm{Ca}-\mathrm{Na}-\mathrm{Mg}-\mathrm{Cl}-\mathrm{SO}_{4}$ water type, where the absence of the predominant ions refers to the contribution of different water sources to the groundwater recharge in this area. The groundwater recharge through the soil cover could be negligible in this area; this related to the hydraulic properties of the soil. However, the infiltration rate through soil profiles is also related to land use (USAD 2000). Thus, the infiltration rates in the arable fields must be much higher than in forests in this area. The impervious area and other urban facilities should significantly reduce the groundwater recharge. Therefore, different mechanism and important spatial variations predominant the groundwater recharge in the Lottenbachtal catchment area.

\section{Conclusion}

The Lottenbachtal is characterized by very complex hydrological and hydrogeological characteristics due to the variety of land uses and the complex geological structure. The mining activities of the Ruhr Carboniferous disturbed the natural hydrogeological conditions by conduits, represented by drainage shafts. These features have relatively high flow velocities. The mining shafts intersect with other tectonic and lithological feature forming a complex groundwater flow system. The soil cover of the study area has extremely low hydraulic conductivity, which increases the direct surface runoff and reduces the groundwater recharge. The settlement areas also increase the direct surface runoff and reduce the groundwater recharge due to the large impervious areas. For this reason, the direct surface runoff generated in this area is extremely high in comparison with the other components of the hydrologic cycle. The groundwater recharge occurs chiefly by the mining and the tectonic features. The limited extension of the mining facilities and the low hydraulic conductivities of the unsaturated zone and the aquifer are responsible for the low groundwater recharge. The absence of the predominant water types in most of the water sources in this area is another result of the impact of the land use diversity, where the surface water and the groundwater flow through different flow paths and feed each other. The rainy days are characterized by the precipitation value ranged between 0.1 and $5 \mathrm{~mm} /$ day. The most common relative humidity values ranged between 55 and $80 \%$. The most predominant minimal air temperature ranged between 0 and $15^{\circ} \mathrm{C}$, while the most predominant maximal air temperatures ranged between 5 and $15^{\circ} \mathrm{C}$. The actual evapotranspiration constitutes $31.90 \%$ of the total precipitation, while the direct surface runoff constitutes $61.04 \%$, the soil water constitutes $3 \%$ and the groundwater recharge constitutes only $4 \%$ of the total precipitation.

Acknowledgments The scientific scholarship for this work was provided by the University of Damascus, Syrian Arab Republic. Laboratory works has been done in the Department of Applied Geology at the Ruhr University Bochum. The Author would like to thank all the technicians and scientific staffs who have contributed to the completion of this work.

Open Access This article is distributed under the terms of the Creative Commons Attribution License which permits any use, distribution, and reproduction in any medium, provided the original author(s) and the source are credited.

\section{References}

Alhamed M (2014) Identification of the geochemical processes controlling the neutralization of abandoned coal mine drainage using integration of geochemical modelling, geochemical analysis and batch test, in the South of Bochum Germany. (submitted)

Alhamed M, Wohnlich S (2014a) Environmental impact of the abandoned coal mines on the surface water and the groundwater in the south of Bochum, Germany. Environ Earth Sci 72(9): 3251-3267

Alhamed M, Wohnlich S (2014b) Hydrochemical responses during and after storm events and hydrograph separation in the Lottental catchment area, Bochum, Germany (submitted)

Bagrov NA (1953) Über den vieljährigen Durchschnittswert der Verdunstung von der Oberfläche des Festlandes. Met i Gidrol 10:20-25

Banks D, Younger P, Arnesen RT, Iversen ER, Banks SB (1997) Mine-water chemistry: the good, the bad and the ugly. Environ Geol 32(3):157-174 
Blodgett S, Kuipers JR (2002) Underground hard-rock mining: subsidence and hydrologic environmental impacts. Center for Science in Public Participation, Bozeman, p 45

Cleaves ET (2003) Conceptual model for transferring information between small watersheds. Environ Geol 45(2):190-197

Davie T (2008) Fundamentals of hydrology. Routledge, New York

DIN ISO 11265 (1997) Bodenbeschaffenheit-Bestimmung der Spezifischen Elektrischen Leitfähigkeit. Beuth Verlag $\mathrm{GmbH}$, Berlin, 4 S. Title (English): Soil quality-determination of the specific electrical conductivity

DIN EN 12457-2 (2003) Charakterisierung von Abfällen - Auslaugung; Übereinstimungs-Untersuchung für die Auslaugung von Körnigen Abfällen und Schlämmen-Teil 2:Einstufiges Schüttelverfahren mit einem. Beuth Verlag GmbH. Berlin. 32 S. Title (English): Characterization of waste-leaching; compliance test for leaching of granular and sledges-Part 2: one stage batch test at a liquid to solid ratio of $10 \mathrm{l} / \mathrm{kg}$ with particle size below $4 \mathrm{~mm}$

DIN 18121-1 (1998) Untersuchung von Bodenproben-Wassergehalt-Teil 1: Bestimmung durch Ofentrocknung. Beuth Verlag $\mathrm{GmbH}$, Berlin, p 4

DIN 19682-13 (2009) Bodenbeschaffenheit-FelduntersuchungenTeil 13: Bestimmung der Carbonate, der Sulfide, des $\mathrm{pH}$-Wertes und der Eisen(II)-Ionen. Beuth Verlag GmbH, Berlin, $32 \mathrm{~S}$. Title (English): Soil quality-field tests-Part 13: determination of carbonate, sulfide, $\mathrm{pH}$-value and iron (II)-ions

Environmental Law Alliance Worldwide ELAW (2010) Guidebook for evaluating mining project EI. Environmental Law Alliance Worldwide, Eugene, p 110

Geologische Landesamt Nordrhein-Westfalen GLA-NRW (1988) Geologische Karte von Nordrhein-Westfalen 1:25000, Erläuterungen zu Blatt 4509 Bochum, Geologisches Landesamt Nordrhein-Westfalen, Krefeld

Geologisches Landesamt Nordrhein Westfalen GLA-NRWa (1988) Geologische Karte von Nordrhein-Westfalen 1:25000, 4509. Bochum, 2. Aufl. Geologisches Landesamt Nordrhein-Westfalen. Krefeld

Geologisches Landesamt Nordrhein Westfalen GLA-NRWb (1988) Geologische Karte von Nordrhein-Westfalen 1:25000: Boden Karte 1:50000, 4509. Bochum, Geologisches Landesamt Nordrhein-Westfalen. Krefeld

Geologisches Landesamt Nordrhein Westfalen GLA-NRWc (1988) Geologische Karte von Nordrhein-Westfalen 1:25000: Karte der Quartär Mächtigkeit 1:50000, 4509. Bochum, Geologisches Landesamt Nordrhein-Westfalen. Krefeld

Geologisches Landesamt Nordrhein Westfalen GLA-NRWd (1988) Geologische Karte von Nordrhein-Westfalen 1:25000: Hydrogeologische Karte 1:50000, 4509. Bochum, Geologisches Landesamt Nordrhein-Westfalen. Krefeld

Glugla G, Enderlein R, Eyrich A (1976) Das Programm RASTER—ein effektives Verfahren zur Berechnung der Grundwasserneubildung im Lockergestein. Wasserwirtsch Wassertechn 26:377-382

Gregor M (2010) BFI + 3.0: User's manual. Hydro office. Software package for water sciences. Department of hydrogeology, Faculty of Natural Science, Comenius University, Bratislava, Slovakia. pp 21

Grudzielanek M, Steinrücke M, Eggenstein J, Holmgren D, Ahlemann D, Zimmermann B (2011) Das Klima in Bochum, Über 100 Jahre stadtklimatologische Messungen. Geol J 1:34-42

Haude W (1955) Zur Bestimmung der Verdunstung auf möglichst einfache Weise. Mitteilungen Deutscher Wetterdienst, Nr. 11

Hermann W, Hermann G (2008) Die alten Zechen an der Ruhr, Die Blauen Bücher, p 328

Huske J (2006) Die steinkohlenzechen im ruhrrevier: daten und fakten von den anfängen bis 1986, 3rd edn. Deutsches BergbauMuseum, Bochum
Jin X, Xu CH, Zhang Q, Chen YD (2009) Regionalization study of a conceptual hydrological model in Dongjiang basin. South China Quat Int 208(1-2):129-137

Krzeminska DM, Bogaard TA, van Asch ThWJ, van Beek LPH (2012) A conceptual model of the hydrological influence of fissures on landslide activity. Hydrol Earth Syst Sci 16:1561-1576

Landesamt für Natur, Umwelt und Verbraucherschutz NordrheinWestfalen LAVUV (2010) Klima und Klimawandel in Nordrhein-Westfalen-Daten und Hintergründe. Fachbericht 27, Landesamt für Natur, Umwelt und Verbraucherschutz NordrheinWestfalen, Recklinghausen p 60

Langguth HR, Voigt R (2004) Hydrogeologische Methoden. 2. Auflage, Springer, Berlin, Heidelberg, p 1005

Lee H, McIntyre N, Wheater H, Young A (2005) Selection of conceptual models for regionalisation of the rainfall-runoff relationship. J Hydrol 312(1-4):125-147

Lillich W (1970) Vergleich moderner Methoden zur Bestimmung des grundwasseranteils am Gesamtabfluß an der Erdoberfläche Z. dt. Geol Ges Sonderh Hydrogeol Hydrogeochem 17-25 Hannover

Littke R, Malmsheimer KW, Mensink H, Rautenschlein M (1986) Die Geologie im Gebiet des Kemnader Sees südlich Bochum. Bochum: Hrsg. vom Institut für Geologie der Ruhr-Universität Bochum

Mayer B, Feger KH, Giesemann A, Jäger H-J (1995) Interpretation of sulfur cycling in two catchments in the Black Forest (Germany) using stable sulfur and oxygen isotope data. Biogeochemistry 30(1):31-58

Morgenschweis G (2010) Hydrometrie, Theorie und Praxis der Durchflussmessung in offenen Gerinnen. Springer, Heidelberg, Dordrecht, London, p 582

Nilssen JP (1980) Acidification of a small watershed in southern norway and some characteristics of acidic aquatic environments. Int Revue ges Hydrobiol Hydrogr 65:177-207

Renger M, Wessolek G (1990) Auswirkungen von Grundwasserabsenkung und Nutzungsänderung auf die Grundwasserneubildung. Mitt Inst für Wasserwesen Univ der Bundeswehr München, Heft 386: 295-307

Ruelland D, Ardoin-Bardin S, Collet L, Roucou P (2012) Simulating future trends in hydrological regime of a large Sudano-Sahelian catchment under climate change. J Hydrol 424-425:207-216

Schumann S, Schmalz B, Meesenburg H, Schröder U (2010) Status and perspectives of hydrology in small basins. Results and recommendations of the international workshop in GoslarHahnenklee, Germany, 2009 and Inventory of Small Hydrological Research Basins. IHP/HWRP-BERICHTE Heft 10 Koblenz, p 69

Sloto RA, Crouse MY (1996) HYSEP: A computer program for streamflow hydrograph separation and analysis. US Geological Survey, Water-Resources Investigations Report 96-4040, Pennsylvania, $46 \mathrm{p}$

The Food and Agriculture Organization of the United Nations FAO (1993) Field measurement of soil erosion and runoff. Natural Resources Management and Environment. Food and Agriculture Organization of the United Nations, Rome, http://www.fao.org/ docrep/t0848e/t0848e00-.HTM

Tursun I (2012) Räumliche Verteilung von Hydrogeologischen und Hydraulischen Parametern im Lottental, südlich Bochum. Masterarbeit Institut für Geologie, Mineralogie und Geophysik in der Ruhr-Universität Bochum, p 80

United States department of agriculture (USAD) (2007) Hydrologic soil groups: in, hydrology national engineering handbook. Chapter 7, United States department of agriculture and Natural resources conservation service, $42 \mathrm{p}$ 
United States Department of Agriculture USAD (2000) Hydrologic effects of land use and treatment: hydrology national engineering handbook, Chapter 12, United States Department of Agriculture and Natural Resources Conservation Service, $\mathrm{p} 12-8$

Viebahn-Sell (2001). Konzept zur Naturnahen Entwicklung des Lottenbachs. Unveröffent-lichtes Gutachten im Auftrag des Tiefbauamtes der Stadt Bochum. Stadt Bochum, Tiefbauamt. Bochum. p 69

Viebahn-Sell (2006). Immissionsbetrachtung der Einleitungen in den Lottenbach,Phase I Gewässerökologische Bestandaufnahme und Bewertung. Unveröffentlichtes Gutachten im Auftrag des
Tiefbauamtes der Stadt Bochum. Stadt Bochum, Tiefbauamt. Bochum. p 85

Wegehenkel M (2002) Estimating of the impact of land use changes using the conceptual hydrological model THESEUS - a case study. Phys Chem Earth Parts A/B/C 27(9-10):631-640

Younger PL (2003). Impacts of mining on physical hydrogeology. In Prokop, G., Younger, P. and Roehl, K. E. (ed.) (2003) Groundwater management in mining areas. Proceedings of the 2nd Image-Train advanced study course, Federal Environment Agency, Wien/Vienna, 110 p. http://www.Umweltb-undesamt. at/fileadmin/site/publikationen/CP035.pdf 